NOTE

\title{
Multicentric infiltrative lipoma in a farmed Mediterranean seabass Dicentrarchus labrax: a pathological and biochemical case study
}

\author{
F. Marino ${ }^{1, *}$, B. Chiofalo ${ }^{2}$, G. Mazzullo ${ }^{1}$, A. Panebianco ${ }^{1}$ \\ ${ }^{1}$ Department of Veterinary Public Health and ${ }^{2}$ Department of Morphology, Biochemistry, Physiology and \\ Animal Production, Faculty of Veterinary Medicine, University of Messina, Polo Universitario dell'Annunziata, \\ 98168 Messina, Italy
}

\begin{abstract}
A tumour diagnosed as multicentric infiltrative lipoma affecting a single farmed seabass is described. The fish had 3 masses on the lateral side of its back, deforming the skin surface. The masses showed a tendency to invade the underlying musculature. Histologically, the neoplasm consisted of differentiated adipocytes. Biochemically, the neoplastic tissue showed lower values of monounsaturated fatty acids and higher values of polyunsaturated fatty acids compared with adjacent normal muscular tissue, particularly of the n3 series, such as eicosapentanoic $\left(C_{20: 5 n 3}\right)$ and docosahexanoic $\left(\mathrm{C}_{22: 6 \mathrm{n} 3}\right)$ acids. Data obtained suggest a metabolic disturbance in the lipid component of the muscular tissue metabolic pathway, which could be the starting point to promote lipoma formation. This is the first report of lipoma in Mediterranean seabass.
\end{abstract}

KEY WORDS: Lipoma $\cdot$ Tumour $\cdot$ Seabass $\cdot$ Fatty acid

\section{INTRODUCTION}

The Mediterranean seabass Dicentrarchus labrax is one of the most important teleostean species for the farming industry in the Mediterranean Sea. Although infectious and parasitic diseases have been widely studied in this fish, no reports concerning tumours are available in the literature. The Regulation (EC) No. 852/2004 imposes the obligation for primary producers to register diseases and other hygiene and health problems. Careful semeiotic and pathological screenings may be enough to help to meet such obligations. This Note results from such a health control performed on a fish farm and describes a spontaneously occurring tumour in a farmed Mediterranean seabass.

Some previous investigations aimed at comparing biochemical characteristics of the lipid component of the normal and neoplastic muscular tissue are very interesting and stimulate further in-depth examinations. As early as 1963, Jacob observed a higher fatty acid synthesis in human lipoma (Jacob 1963). Singer et al. (1997), trying to define the malignancy grading, found important qualitative and quantitative differences among the fatty acids in normal fat, welldifferentiated liposarcomas, dedifferentiated liposarcomas and pleomorphic liposarcomas; in particular, they observed an increase in the degree of polyunsaturation in the dedifferentiated and pleomorphic liposarcomas compared with the well-differentiated liposarcoma. Hietanen et al. (1986) reported no significant differences in the fatty acid content of lipoma compared with healthy tissue, but a marked increase in the relative amounts of unsaturated fatty acids, especially arachidonic acid, and a decrease in saturated fatty acids in mammary cancers compared with healthy reference tissue or lipomas. Park et al. (1996) 
demonstrated an increase in lipoprotein lipases in lipomatous tissue compared with close healthy tissue, confirming that the subunits mainly secreted in lipomas were those with a weight of $55 \mathrm{kDa}$. Also, Solvonuk et al. (1984) found a higher number of preadipocytes and a higher level of lipoproteinlipases in lipomas compared with physiological fat tissue, with direct influences on the growth ability of the tumour. The lipoprotein lipase is an enzyme of the hydrolase class that catalyzes the reaction of triacylglycerol and water to yield diacylglycerol and a fatty acid anion; it occurs on the capillary endothelial surfaces, especially in mammary, muscle and adipose tissue. When the activity of this enzyme increases, such as in lipomas, there is a greater level of fatty acids, freed from the glycerol, than in normal fat (Park et al. 1996). Similar influences were also suggested by Sarkisov et al. (1984), who stated that differentiation of lipomas is supported by the vascular cells. Recently, studies (Wohlgemuth 2010) have reported that changes in lipid profiles can mark development stages, or more ominously, pathological states such as neurodegenerative disorders and metabolic disorders; additionally, research is now trying to explain how dysregulations in lipid metabolism may underlie certain forms of cancer, underlining the use of lipids as biomarkers.

A new approach to the investigation of lipoid neoplasms through the analysis of the lipid component of normal and pathological muscular tissue of fatty acid content, as potential indicators of the aetiology, is proposed here.

\section{MATERIALS AND METHODS}

An adult seabass approximately $400 \mathrm{~g}$ in weight, originating from a local fish farm located in the Tyrrhenian Sea (Italy), was examined. The farming system was based on 8 seafloating cages $(15 \times 15 \times 15 \mathrm{~m})$, rearing 10000 fish (Mediterranean seabass and gilthead sea bream) per cage, fed with commercial food.

Normal and pathological muscular tissues from the area of the lesions were sampled, fixed in 10\% buffered formalin solution and embedded in paraffin wax. Sections (5 $\mu \mathrm{m}$ thick) were stained with haematoxylin \& eosin.

Similar fresh samples were collected to analyze the lipid profile. Specifically, one sample (A) consisted exclusively of pathological muscular tissue from the largest nodule, whereas another sample (B) consisted only of normal muscular tissue from contiguous districts.

For both types of tissue samples, the total lipids were extracted from homogenized tissue by the method of Folch et al. (1957) using a mixture of chloroform/ methanol $(2: 1, \mathrm{v} / \mathrm{v})$. The fatty acids methyl esters
(FAMEs) of the fat were prepared by direct transesterification with sulphuric acid/methanol $(1: 9, \mathrm{v} / \mathrm{v})$ of the weighted portion $(15 \mathrm{mg}$ ) of the total lipids (Christie 1993) and analysed using a SHIMADZU 17A gaschromatograph, operated with a split/splitless injector, a flame ionization detector and fused silica capillary column OMEGAWAX 250 (Supelco), $30 \mathrm{~m} \times 0.25 \mathrm{~mm}$ internal diameter, $0.25 \mu \mathrm{m}$ film thickness. Column temperature was programmed as follows: from 160 to $190^{\circ} \mathrm{C}$ with increments of $2^{\circ} \mathrm{C} \mathrm{min}^{-1}$ and from 190 to $230^{\circ} \mathrm{C}$ with a final isotherm of $250^{\circ} \mathrm{C}(30 \mathrm{~min})$. The temperatures of the injector and detector were 265 and $275^{\circ} \mathrm{C}$, respectively. The injection volume was $1.0 \mu l_{\text {; }}$ the carrier gas was helium $\left(1.2 \mathrm{ml} \mathrm{min}^{-1}\right)$; and the split ratio was 1:50 (Salvo et al. 1998). Identification of fatty acids was made by comparing the relative retention times of FAME peaks from samples with standards from Supelco. Chromatogram peak areas were acquired and calculated by CLASS-VP software and expressed as a percentage of the identified total FAMEs.

On the basis of the fatty acids identified, the quality indices were calculated using the following equations proposed by Ulbricht \& Southgate (1991):

Atherogenic index $=\frac{\mathrm{C} 12: 0+(4 \times \mathrm{C} 14: 0)+\mathrm{C} 16: 0}{\mathrm{n}-6 \text { PUFA }+\mathrm{n}-3 \text { PUFA }+ \text { MUFA }}$

Thrombogenic index =

$\mathrm{C} 14: 0+\mathrm{C} 16: 0+\mathrm{C} 18: 0$

$(0.5 \times$ MUFA $)+(0.5 \times \mathrm{n}-6$ PUFA $)+(3 \times \mathrm{n}-3$ PUFA $)$ $+(\mathrm{n}-3$ PUFA/n-6 PUFA)

The data relating to fatty acid composition were analyzed by ANOVA using the GLM procedure of SAS (2001) with a model that included the variable type of tissues (pathological vs. normal muscular tissues) and the experimental error. The analysis of each tissue was replicated 3 times and the results of each sample were considered as experimental units.

Differences were considered significant at $\mathrm{p}<0.05$.

\section{RESULTS}

At external examination, the specimen showed a prominent deformation of the left side of the body due to the presence of 3 large masses protruding towards the surface (Fig. 1). The overlying epidermis was normal. The 3 lumps were irregularly spherical, firm and slightly elastic in consistency. The largest mass had a diameter of approximately $40 \mathrm{~mm}$. At the cut surface, the tissue was light grey in color with some light pink areas, resembling muscle tissue, and showed a lardaceous texture. The novel tissue had gradually infil- 


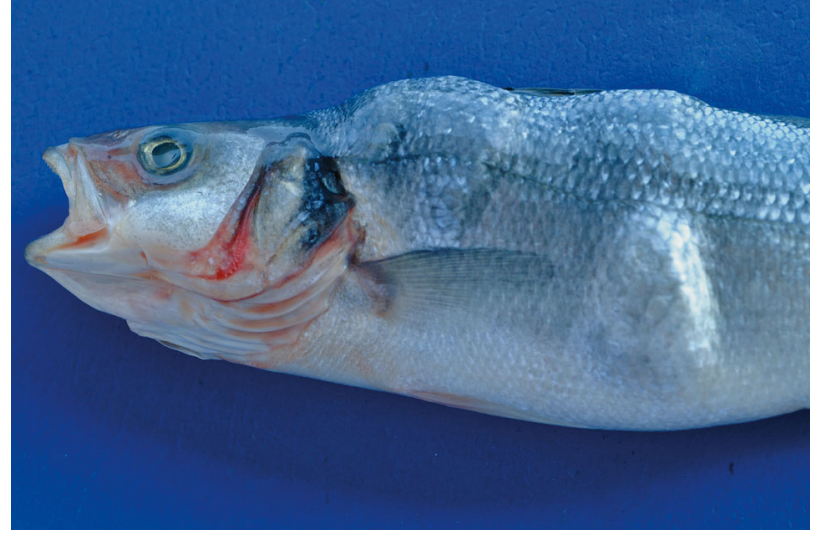

Fig. 1. Dicentrarchus labrax. Macroscopical appearance of the tumours deforming the body dorso-laterally

trated and replaced the muscle tissue, and the latter was sometimes detected within the growth. The masses had no capsule, some margins were distinct, and sometimes finger-like infiltrations of the muscles were present (Fig. 2). Small hemorrhages were rarely detected. The remaining body organs and tissues were normal at pathological examination. Histologically, at low magnification, the muscular tissue was replaced by a lipomatous growth. The neoplastic tissue was characterized by well-differentiated mature adipocytes containing a single large fat vacuole, without evidence of mitoses. Fat cells were uniform, although they sometimes appeared clearly pleomorphic. Only at small foci were cellular elements with features resembling preadipocytes visible; these were mainly very small, sharply indented cells with cytoplasm containing several vacuoles and free lipid drops. Adipocytes without nuclei but with a continuous cytoplasmic membrane and fat cells which apparently disturbed the integrity of the membrane and formed a steatonecrotic feature were also detected in some areas of the tissue sections. In these areas, adipocytes often appeared concentrically arranged in sheets. A few scattered blood vessels and sometimes small hemorrhages were seen. As already described at necropsy, a finger-like infiltration of the underlying muscle tissue (Fig. 3) was observed in several portions of the pathological tissue. Muscle fibers immediately close to the growths were characterized by severe regressive changes, such as thickening of myofibres, granular degeneration with fragmentation and hyalinization, and nuclear dislocation. In some fields, close to such areas, pathological changes resembling a fat metaplasia presumably of interstitial origin, i.e. more than a simple fat infiltration of the muscle, were detected.

Results of the ANOVA performed on the fatty acid classes, fatty acid ratios, quality indices (which are, from a nutritional point of view, strictly correlated to patholog-

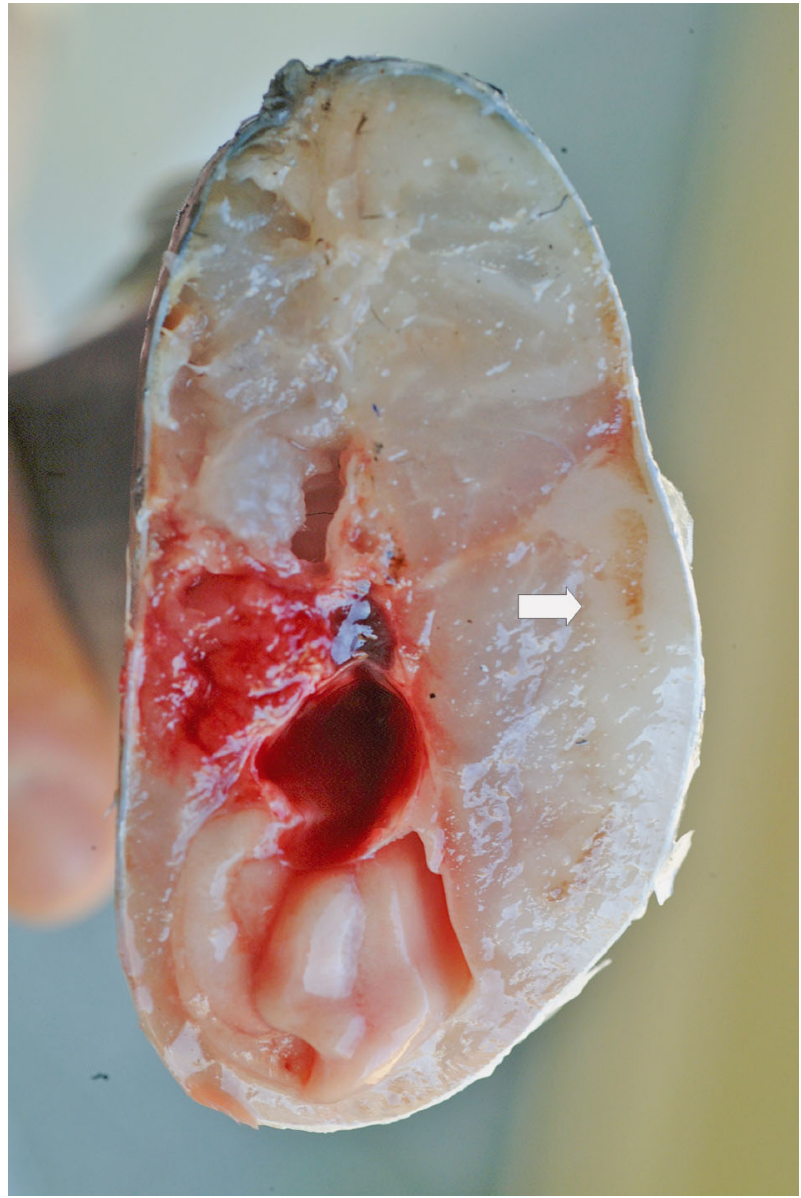

Fig. 2. Dicentrarchus labrax. Cut section of the mass showing a homogeneous texture and the tendency of the pathological tissue to invade muscle tissue with fingler-like infiltrations (arrow)

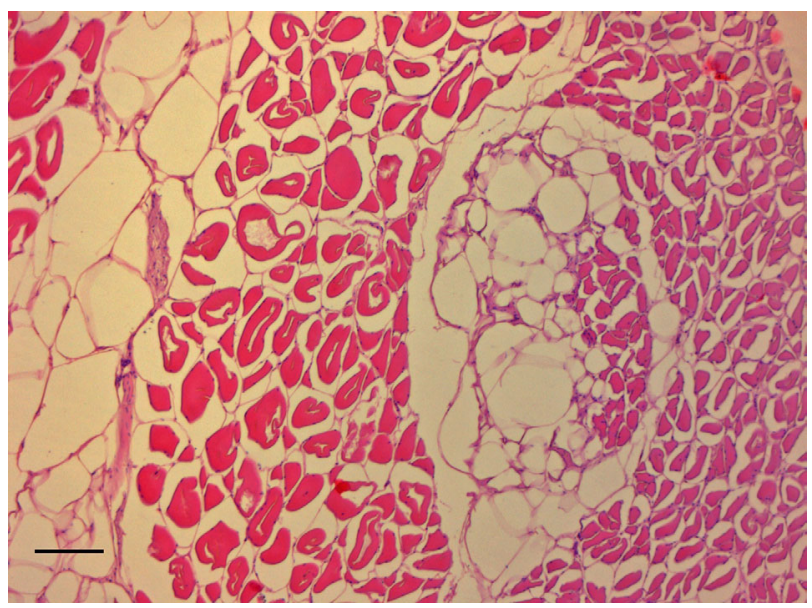

Fig. 3. Dicentrarchus labrax. Histological section (haematoxylin \& eosin) showing a finger-like infiltration of the tumour tissue towards the underlying slightly degenerated muscle tissue. Scale bar $=50 \mu \mathrm{m}$ 
ical phenomena such as the formation of atheroma and/or thrombus) and fatty acid profiles obtained from the neoplastic (Sample A) and normal (Sample B) muscular tissues are reported in Tables 1 and 2.

The saturated fatty acids (SFAs) showed similar values in both samples (A: $27.99 \%$ vs. B: $27.11 \%$; p = 0.325), whereas significant differences between the samples were observed for the monounsaturated fatty acids (MUFAs), which showed lower $(p=0.005)$ values in the neoplastic sample $(38.46 \%)$ than in the normal sample $(43.44 \%)$, and for the polyunsaturated fatty acids (PUFAs) which showed higher $(p=0.009)$ values in the neoplastic sample $(33.54 \%)$ than the normal sample $(29.45 \%$; Table 1$)$. In particular, the main differences in the MUFAs were observed (Table 2 ) for the vaccenic $\left(C_{18: 1 n 7 i} p=0.002\right)$, gadoleic $\left(C_{20: 1 n 9 i} p=0.013\right)$ and cetoleic $\left(\mathrm{C}_{22: 1 \mathrm{n} 11} ; \mathrm{p}=0.001\right)$ acids; in terms of the PUFAs, the neoplastic sample showed higher ( $p<$ $0.001)$ fatty acid content for the $\mathrm{n} 3$ series $(24.86 \%)$ than those for the normal sample $(21.07 \%$; Table 1$)$. These differences were related to the higher content of eicosapentanoic (EPA; $\left.\mathrm{C}_{20: 5 n 3 i} \mathrm{p}=0.007\right)$ and docosahexanoic $\left(\mathrm{DHA}_{i} \mathrm{C}_{22: 6 n 3 i} \mathrm{p}=0.005\right)$ acids in Sample A (7.63 and $11.64 \%$, respectively) than in Sample B (6.13 and $9.96 \%$, respectively; Table 2). PUFAs of the n6 series showed similar $(p=0.119)$ percentages in both muscular samples (Table 1). The ratio of PUFAs to PUFAs+MUFAs (PUFAs:UFAs ratio), which is a measure of the degree of polyunsaturation, showed a significantly $(p=0.020)$ higher value in the pathological tissue than in the normal muscular tissue (Table 1). No significant differences were observed (Table 1) for the ratio of UFAs to SFAs $(p=0.222)$ or for the 2 quality indices, atherogenic $(p=0.451)$ and thrombogenic $(p=$ 0.351), calculated on the basis of the fatty acid profile

Table 1. Least-squares mean (LSM), standard error of the mean (SEM) and p-values of the percentage of the fatty acid classes, fatty acid ratios and quality indices in the pathological (Sample A) and normal (Sample B) muscular tissues. Percentages are expressed on the basis of the identified total fatty acid methyl esters. MUFA: monounsaturated fatty acid; PUFA: polyunsaturated fatty acid; SFA: saturated fatty acid; UFA: unsaturated fatty acid

\begin{tabular}{|c|c|c|c|c|}
\hline Parameter & $\begin{array}{l}- \text { LS } \\
\text { Sample A }\end{array}$ & $\begin{array}{l}\mathrm{M}- \\
\text { Sample B }\end{array}$ & SEM & $\mathrm{p}$ \\
\hline Sum SFAs & 27.99 & 27.11 & 0.19 & 0.325 \\
\hline Sum MUFAs & 38.46 & 43.44 & 0.35 & 0.005 \\
\hline Sum PUFAs & 33.54 & 29.45 & 0.27 & 0.009 \\
\hline Sum n3 PUFAs & 24.86 & 21.07 & 0.17 & $<0.001$ \\
\hline Sum n6 PUFAs & 8.69 & 8.38 & 0.09 & 0.119 \\
\hline PUFAs:UFAs & 0.47 & 0.40 & 0.01 & 0.020 \\
\hline UFAs:SFAs & 2.575 & 2.7 & 0.05 & 0.222 \\
\hline Atherogenic index & 0.445 & 0.45 & 0.01 & 0.451 \\
\hline Thrombogenic index & 0.245 & 0.28 & 0.01 & 0.351 \\
\hline
\end{tabular}

Table 2. Least-squares means (LSM), standard error of the mean (SEM) and p-values of the percentages of the fatty acid profile in the pathological (Sample A) and normal (Sample B) muscular tissues. Percentages are expressed on the basis of the identified total fatty acid methyl esters. ARA: arachidonic acid; DHA: docosahexanoic acid; EPA: eicosapentanoic acid; MUFA: monounsaturated fatty acid; PUFA: polyunsaturated fatty acid; SFA: saturated fatty acid; UFA: unsaturated fatty acid

\begin{tabular}{|c|c|c|c|c|}
\hline \multirow[t]{2}{*}{ Fatty acid } & \multicolumn{2}{|c|}{$\longrightarrow$ LSM -} & \multirow[t]{2}{*}{ SEM } & \multirow[t]{2}{*}{$\mathrm{p}$} \\
\hline & Sample A & Sample B & & \\
\hline \multicolumn{5}{|l|}{ SFAs } \\
\hline $\mathrm{C}_{14: 0}$ & 3.605 & 3.62 & 0.06 & 0.628 \\
\hline $\mathrm{C}_{15: 0}$ & 0.365 & 0.38 & 0.01 & 0.117 \\
\hline $\mathrm{C}_{16: 0}$ & 18.075 & 18.42 & 0.36 & 0.089 \\
\hline $\mathrm{C}_{17: 0}$ & 0.35 & 0.3 & 0.01 & 0.222 \\
\hline $\mathrm{C}_{18: 0}$ & 3.465 & 3.77 & 0.07 & 0.074 \\
\hline $\mathrm{C}_{20: 0}$ & 0.38 & 0.32 & 0.01 & 0.088 \\
\hline $\mathrm{C}_{22: 0}$ & 0.23 & 0.2 & 0.01 & 0.321 \\
\hline $\mathrm{C}_{24: 0}$ & 0.055 & 0.1 & 0.01 & 0.057 \\
\hline \multicolumn{5}{|l|}{ MUFAs } \\
\hline $\mathrm{C}_{16: 1 \mathrm{n} 7}$ & 5.145 & 5.32 & 0.06 & 0.115 \\
\hline $\mathrm{C}_{17: 1}$ & 0.32 & 0.3 & 0.01 & 0.552 \\
\hline $\mathrm{C}_{18: \ln 9}$ & 22.055 & 22.27 & 0.21 & 0.114 \\
\hline $\mathrm{C}_{18: \ln 7}$ & 1.905 & 2.96 & 0.03 & 0.002 \\
\hline $\mathrm{C}_{20: 1 \mathrm{n} 9}$ & 5.025 & 5.96 & 0.07 & 0.013 \\
\hline $\mathrm{C}_{20: 1 \mathrm{n} 7}$ & 0.625 & 0.73 & 0.02 & 0.052 \\
\hline $\mathrm{C}_{22: 1 \mathrm{n} 11}$ & 4.08 & 5.19 & 0.05 & 0.001 \\
\hline $\mathrm{C}_{22: 1 \mathrm{n} 9}$ & 0.565 & 0.7 & 0.02 & 0.050 \\
\hline \multicolumn{5}{|l|}{ n3 PUFAs } \\
\hline $\mathrm{C}_{18: 3 \mathrm{n} 3}$ & 1.605 & 1.49 & 0.02 & 0.110 \\
\hline $\mathrm{C}_{18: 4 \mathrm{n} 3}$ & 1.285 & 1.03 & 0.02 & 0.111 \\
\hline $\mathrm{C}_{20: 3 \mathrm{n} 3}$ & 0.3 & 0.19 & 0.01 & 0.042 \\
\hline $\mathrm{C}_{20: 4 \mathrm{n} 3}$ & 0.865 & 0.66 & 0.01 & 0.054 \\
\hline $\mathrm{C}_{20: 5 \mathrm{n} 3} \mathrm{EPA}$ & 7.63 & 6.13 & 0.11 & 0.007 \\
\hline $\mathrm{C}_{21: 5 \mathrm{n} 3}$ & 0.345 & 0.42 & 0.01 & 0.099 \\
\hline $\mathrm{C}_{22: 5 \mathrm{n} 3}$ & 1.345 & 1.18 & 0.02 & 0.231 \\
\hline $\mathrm{C}_{22: 6 \mathrm{n} 3} \mathrm{DHA}$ & 11.635 & 9.96 & 0.06 & 0.005 \\
\hline \multicolumn{5}{|l|}{ n6 PUFAs } \\
\hline $\mathrm{C}_{18: 2 \mathrm{n} 6}$ & 6.47 & 6.44 & 0.05 & 0.221 \\
\hline $\mathrm{C}_{18: 3 \mathrm{n} 6}$ & 0.21 & 0.22 & 0.01 & 0.366 \\
\hline $\mathrm{C}_{20: 2 \mathrm{n} 6}$ & 0.23 & 0.19 & 0.01 & 0.085 \\
\hline $\mathrm{C}_{20: 3 \mathrm{n} 6}$ & 0.78 & 0.71 & 0.02 & 0.221 \\
\hline $\mathrm{C}_{20: 4 \mathrm{n} 6}$ ARA & 1.065 & 0.83 & 0.03 & 0.042 \\
\hline
\end{tabular}

determined in both samples. In fact, SFAs with a chain length of 14,16 or 18 carbon atoms have been suggested to be thrombogenic (Hornstra \& Lussenberg 1975), whereas SFAs with a chain length of 12, 14 or 16 carbon atoms have been suggested to be atherogenic. The MUFAs, n-3 PUFAs and n-6 PUFAs have been shown to reduce plasma triacylglycerols, thromboxane B2 and platelet activity and prolong bleeding time and heparin-thrombin clotting time (Burr 1989). Therefore, Ulbricht \& Southgate (1991), in an attempt to take into account the different effects of the various fatty acids, proposed atherogenic and thrombogenic indices that might better characterize the atherogenic and thrombogenic potential than simple approaches such as total SFAs or the ratio of PUFAs to SFAs (Fehily et al. 1994). 


\section{DISCUSSION}

All the features described by the macroscopic and microscopic examinations were consistent with a diagnosis of a multicentric infiltrative lipoma. Histologically, the neoplasm was mainly constituted of welldifferentiated adipocytes, without evidence of mitosis and with a sharp tendency to infiltrate the surrounding tissues, as reported in lipomas of higher vertebrates. Blood vessels were present, although not involved in neoplastic transformation, permitting a differential diagnosis with angiolipoma.

According to the World Health Organization International Histological Classification of Tumours of Domestic Animals (Hendrick et al. 1998), tumours arising from adipose tissue are classified as either benign (lipoma and angiolipoma) or malignant (liposarcoma). Lipoma is a benign tumour of well-differentiated adipocytes that is found in most domestic animals (Goldschmidt \& Hendrick 2002) as well as humans. Histologically, a lipoma is often indistinguishable from normal adipose tissue. Lipomas are localized nodules of fat with an otherwise normal appearance and only their lumpy appearance has justified their traditional inclusion as neoplasms (Yager \& Scott 1985). This mesenchymal neoplasm has been reported in both freshwater and marine fish, where it is, however, considered a rare tumour; indeed, it has never been reported before in seabass. Lipomatous neoplasms (lipomas, liposarcomas, fibrolipomas, etc.) have been described in bream Abramis brama (MawdesleyThomas \& Bucke 1968), rockfish Sebastodes diploproa (Harshbarger \& Bane 1969), catfish Ictalurus punctatus (McCoy et al. 1985), mullet Mugil cephalus (Easa et al. 1989), wild dab Limanda limanda (Bruno et al. 1991), farmed striped seabream Lithognathus mormyrus (Volpatti et al. 1998), farmed halibut Hippoglossus hippoglossus (Bambir et al. 2000), Thunnus spp. (Munday et al. 2003), farmed northern blue fin tuna Thunnus thynnus (Marino et al. 2006), farmed southern bluefin tuna Thunnus maccoyii (Lester \& Kelly 1983, Johnston et al. 2008), largemouth bass Micropterus salmoides (Mawdesley-Thomas 1972) and black crappie Pomoxis nigromaculatus (Harshbarger 1972). Infiltrative lipomas with similar characteristics to those described here have been reported from I. punctatus (McCoy et al. 1985), Platycephalus bassensis (Hard et al. 1979) and T. maccoyii (Johnston et al. 2008).

Data for fatty acid profile indicate a greater level of PUFAs in the pathological than the normal muscular tissue; this was also confirmed by the higher degree of polyunsaturation. Our observations do not fit with those of Hietanen et al. (1986) when they, comparing fatty acid content in lipoma and healthy tissue, report did not observe significant differences, while, are in accordance with this study when authors described a marked increase of the desaturation degree and of the arachidonic acid in mammary cancers compared with a healthy reference tissue or lipomas. As a possible explanation, Hietanen et al. (1986) suggest that fatty acids might have a role in the development of cancer, possibly related to the formation of reactive metabolites of UFAs in the initiation of cancer or to their promotional effects.

In addition, Singer et al. (1997) reported an increase in the degree of the levels of PUFA:UFA ratios in the dedifferentiated and pleomorphic liposarcomas compared with well-differentiated liposarcoma, indicating that (1) the lipid metabolites function as biomarkers to predict metastatic potential and risk of recurrence in patients with liposarcoma and (2) the fatty acid changes are sarcoma specific. Moreover, our results show that EPA, DHA and arachidonic acid (ARA) are responsible for the higher degree of polyunsaturation in the pathological tissue compared with the normal muscular tissue; these long-chain PUFAs derived, through desaturase and elongase enzyme activity, from the linolenic and linoleic acids, which showed no significant difference in both muscular tissues. Therefore, the observed increase of long-chain PUFAs in this study could be related to the degree of neoplastic cell differentiation, which depends on gene expression and the hormonal environment, with the associated phenotypic change in fatty acid synthesis and degradation, as reported by Singer et al. (1997). Thus, these histological types of liposarcoma represent a spectrum of adipocyte differentiation that may be quantitatively characterized by their lipid metabolites (Singer et al. 1997), which, in our study showed a marked increase of the long-chain fatty acid synthesis in the pathological muscular tissue.

In conclusion, data suggest that metabolomic research of lipids and lipid metabolites (lipidomic) is essential not only for enhancing the understanding of different influences such as genetic, nutritional, behavioral and environmental factors, but also for the study of healthy and diseased cells (Wohlgemuth 2010). Lipoma is by definition benign, whereas infiltrative lipoma has infiltrative and destructive characteristics, suggesting malignancy. It has therefore been suggested that this form actually represents a welldifferentiated liposarcoma (Saik et al. 1987, Fletcher \& McKee 1992).

Because of the rarity of tumours of fat tissue in fish and the scarce availability of data in the literature, it is only possible to hypothesize on their etiopathogenesis. The aetiology of lipoma development is unknown, even if an error in fat metabolism (Easa et al. 1989, Pulley \& Stannard 1990) or endocrine or neurological dysfunctions (Easa et al. 1989) have been proposed as possible causes, suggesting that lipoma development 
may be due to excessive differentiation of interstitial mesenchymal cells into adipocytes, a form of hyperplasia (Pulley \& Stannard 1990).

However, it is reasonable to assume that in such neoplasms, including the case described here, a dismetabolic disturbance may be encountered. In farmed fish, aspects regarding the qualitative and quantitative profiles of the lipid component of the muscular tissue are complex and sometimes enigmatic. In our opinion, the dysmetabolic syndrome may be the starting point to promote lipoma formation, and this assumption may help to explain the relative frequency of lipomas compared with other tumours in farmed fish. Although similar tumours have been described in wild fish, we suggest that farming in itself may induce such a relative increase in frequency through management issues. However, the increase may also be explained by the fact that veterinary controls make it easier to detect such lesions in farmed fish.

\section{LITERATURE CITED}

Bambir S, Helgason S, Marino F, Macrì B (2000) Some interesting tumours in fish. 11th Ljudevit Jurak International Symposium on Comparative Pathology, June 2000, Zagreb

Bruno DW, Mc Vicar AH, Fraser CO (1991) Multiple lipoma in the common dab, Limanda limanda L. J Appl Ichthyol 7: $238-243$

Burr ML (1989) Fish and the cardiovascular system. Prog Food Nutr Sci 13:291-316

Christie WW (1993) Preparation of ester derivatives of fatty acids for chromatographic analysis. In: Christie WW (ed) Advances in lipid methodology, Vol II. The Oily Press, Dundee, $\mathrm{p}$ 69-111

Easa MEl S, Harshbarger JC, Hetrick FM (1989) Hypodermal lipoma in a striped (grey) mullet Mugil cephalus. Dis Aquat Org 6:157-160

Fehily AM, Pickering JE, Yarnell JWG, Elwood PC (1994) Dietary indices of atherogenicity and thrombogenicity and ischaemic hearth disease risk: the Caerphilly Prospective Study. Br J Nutr 71:249-257

Fletcher CDM, McKee PH (1992) Soft tissue tumours. In: McGee JOD, Isaacson PG, Wright NA (eds) Oxford textbook of pathology, Vol 2b: pathology of systems. Oxford University Press, Oxford, p 2103-2106

Folch J, Lees M, Sloane-Stanley GHS (1957) A simple method for the isolation and purification of total lipids from animal tissue. J Biol Chem 226:497-500

Goldschmidt MH, Hendrick MJ (2002) Tumors of the skin and soft tissues. In: Meuten DJ (ed) Tumors in domestic animals. Iowa State Press, Iowa City, IA, p 45-117

Hard GC, Williams R, Lee J (1979) Survey of demersal fish in Port Phillip Bay for incidence of neoplasia. Aust J Mar Freshw Res 30:73-79

Harshbarger JC (1972) Work of the registry of tumours in lower animals with emphasis on fish neoplasms. Symp Zool Soc Lond 30:285-303

> Harshbarger JC, Bane CW (1969) Case report of fibrolipoma in a rockfish, Sebastodes diploproa. Natl Cancer Inst Monogr 31:219-222

Hendrick MJ, Mahaffey AE, Moore FM, Vos JH, Walder EJ (1998) Histological classification of mesenchymal tumours of skin and soft tissues of domestic animals, Vol 2. Armed
Forces Institute of Pathology, American Registry of Pathology, and the World Health Organization, Washington, DC, p $18-20$

Hietanen E, Punnonen K, Punnonen R, Auvinen O (1986) Fatty acid composition of phospholipids and neutral lipid peroxidation in human breast cancer and lipoma tissue. Carcinogenesis 7:1965-1969

Hornstra G \& Lussenberg R N (1975) Relationship between the type of dietary fatty acid and the arterial thrombus tendency in rats. Atherosclerosis 22:499-516

Jacob MI (1963) Fatty acid synthesis in cell-free preparations of human adipose tissue. Biochim Biophys Acta 70: 231-241

Johnston CJ, Deveney MR, Bayly T, Nowak BF (2008) Gross and histopathological characteristics of 2 lipomas and a neurofibrosarcoma detected in aquacultured southern bluefin tuna, Thunnus maccoyii (Castelnau), in South Australia. J Fish Dis 31:241-247

Lester RJG, Kelly WR (1983) Tumour-like growths from southern Australian marine fish. Tasman Fish Res 25:27-32

Marino F, Monaco S, Salvaggio A, Macrì B (2006) Lipoma in a farmed northern bluefin tuna, Thunnus thynnus (L.). J Fish Dis 29:697-699

Mawdesley-Thomas LE, Bucke D (1968) A lipoma in a bream (Abramis brama L.). Vet Rec 82:673-674

> McCoy CP, Bowser PR, Steeby J, Bleau M, Schwedler TE (1985) Lipoma in channel catfish (Ictalurus punctatus Rafinesque). J Wildl Dis 21:74-76

Munday BL, Sawada Y, Cribb T, Hayward CJ (2003) Diseases of tunas, Thunnus spp. J Fish Dis 26:187-206

> Park JW, Yang JY, Rhee SR, Cho CG and others (1996) Glycosylation of lipoprotein lipase in human subcutaneous lipomas. Horm Metab Res 28:7-10

Pulley LT, Stannard AA (1990) Skin and soft tissues. In: Moulton JE (ed) Tumors in domestic animals, 3rd edn. University of California Press, Berkeley and Los Angeles, CA, p 652-654

Saik JE, Diters RW, Wortman JA (1987) Metastasis of a welldifferentiated liposarcoma in a dog and a note on nomenclature of fatty tumours. J Comp Pathol 97:369-373

Salvo F, Ziino M, Signorino D, Leuzzi U, Dugo G, Chiofalo B, Giuffrida D (1998) Chemical composition on bluefin tuna (Thunnus thynnus L.) from the Strait of Messina Waters. J Food Sci Nutr 27:43-50

Sarkisov DS, Pal'tsyn AA, Adamian AA, Kolokol'chikova EG (1984) Electron microscopic and radioautographic study of nucleic acid synthesis in normal fatty tissue and lipomas. Biull Eksp Biol Med 97:618-621

SAS (2001) SAS ${ }^{\circledR}$ user's guide: statistics, Version 8.2. SAS, Cary, NC

Singer S, Millis K, Souza K, Fletcher C (1997) Correlation of lipid content and composition with liposarcoma histology and grade. Ann Surg Oncol 4:557-563

Solvonuk PF, Taylor GP, Hancock R, Wood WS, Frohlich J (1984) Correlation of morphologic and biochemical observations in human lipomas. Lab Invest 51:469-474

Ulbricht TLV, Southgate DAT (1991) Coronary heart disease: seven dietary factors. Lancet 338:985-992

Volpatti D, Patarnello P, Novelli A, D'Angelo L, Musetti R, Galeotti M (1998) Lipoma, fibrolipoma, liposarcoma in mormore (Lithognatus mormyrus) allevate: osservazioni istologiche e ultrastrutturali. V convegno, Società Italiana di Patologia Ittica (SIPI), Rome

Wohlgemuth R (2010) Lipid metabolites as biomarkers for the differentiation of diseased and healthy cells. Biofiles 5:26-27

Yager JA, Scott DW (1985) Tke skin and appendages. In: Jubb KVF, Kennedy PC, Palmer N (eds) Pathology of domestic animals. Academic Press, London, p 407-549 